\title{
Differences in maize physiological characteristics, nitrogen accumulation, and yield under different cropping patterns and nitrogen levels
}

\author{
Xiangqian Zhang ${ }^{1}$, Guoqin Huang ${ }^{2 *}$, and Qiguo Zhao ${ }^{3}$
}

Intercropping and $\mathrm{N}$ fertilization play an important role in increasing crop yield. In order to further understand the advantage mechanism of intercropping and the effect of increasing $\mathrm{N}$ application on the advantage effect of intercropped crop, a field experiment was conducted to investigate the effects of different cropping patterns (i.e. M, maize monoculture; I1, maize-cotton intercrop; I2, maize-soybean intercrop) and $\mathrm{N}$ fertilization levels (N1, $100 \mathrm{~kg} \mathrm{ha}^{-1}$; N2, $200 \mathrm{~kg} \mathrm{ha}^{-1}$; N3, 300 $\mathrm{kg} \mathrm{ha}^{-1}$; N4, $400 \mathrm{~kg} \mathrm{ha}^{-1}$ ) on maize (Zea mays L.) Results showed that intercropping and increasing $\mathrm{N}$ application could enhance green leaf area per maize plant and chlorophyll content, and differences in green leaf area per plant and chlorophyll content between intercropping and monoculture under N1 were significant. Intercropping and increasing $\mathrm{N}$ application could improve maize photosynthetic characters, but their effects would be decreased with increasing $\mathrm{N}$ fertilization level. Root bleeding sap rate and root DM of maize were also obviously affected by intercropping and $\mathrm{N}$ fertilization, and the differences in root bleeding sap rate and root DM between I2 and M under N1 and N2 were significant. Compared to M, under N1, N2, N3, and N4, I2 increased grain N content by 12.8\%, 6.3\%, 2.7\%, 1.5\%, respectively. Intercropping and increasing $\mathrm{N}$ application could increase maize yield, and the difference in yield between $\mathrm{I} 2$ and $\mathrm{M}$ under N1 was significant. All the findings suggest that intercropping and increasing $\mathrm{N}$ application can improve maize physiological characters and increase maize root DM, $\mathrm{N}$ accumulation and yield, but their effects will be decreased with increasing $\mathrm{N}$ fertilization level.

Key words: Chlorophyll content, nitrogen content, photosynthetic characters, root dry mass yield, Zea mays.

\section{INTRODUCTION}

Intercropping is a cropping pattern with a 1000-yr-old history in Chinese agriculture, and it is still widespread in modern Chinese agriculture. Intercropping has the potential to achieve higher grain yields than monoculture systems by mainly improving the efficient use of water, light, nutrients, and other resources (Li et al., 2011). Enhanced productivity of intercropping compared with monoculture can be explained by two major processes that result in improved resource use: complementarity and facilitation (Fridley, 2001). Complementarity can be defined as a decrease in interspecific competition and competitive exclusion through resource partitioning between intercropped species (Hinsinger et al., 2011). For example, species can use a given resource differently

${ }^{1}$ Crops Research Institute, Anhui Academy of Agricultural Sciences, Hefei, Anhui Province, 230031, P.R. China.

${ }^{2}$ Research Center on Ecological Sciences, Jiangxi Agricultural University, Nanchang, Jiangxi Province, 330045, P.R. China. *Corresponding author(hgqjxnc@sina.com).

${ }^{3}$ Nanjing Institute of Soil Science, Chinese Academy of Sciences, Nanjing, Jiangsu Province, 210008, P.R. China.

Received: 10 December 2013.

Accepted: 14 June 2014.

doi:10.4067/S0718-58392014000300011 based on time, space, and characteristics. Facilitation occurs when one species enhances the growth or survival of another (Callaway, 1995). This can occur through (1) direct positive mechanisms, such as favorable alteration of temperature, light, soil moisture, and nutrients and (2) indirect mechanisms, such as beneficial changes in soil mycorrhizal or microbial communities.

Nowadays, most studies of intercropping have been focused on low-input and low-output systems (Kavamahanga et al., 1995; Hauggaard-Nielsen and Jensen, 2001) to develop organic farming systems. In contrast, intercropping in China has developed using intensive farming systems with high inputs and high outputs, typically cereal/cereal systems. However, the advantageous effect of an intercrop would change due to high fertilizer inputs because soil fertility plays an important role in interspecific interactions between intercrops. For example, some agronomists have indicated that higher nutrient availability aggravates interspecific competition because larger individuals per se occupy a higher development space, intercept more light, and assimilate more nutrient resources and water (Keddy, 1989; Schippers et al., 1999), However, Li et al. (2011) indicated that increasing $\mathrm{N}$ application rates alleviated the competitive intensity of intercrops in cereal/cereal intercropping. 
This study therefore researched the difference in maize (Zea mays L.) physiological characteristics, N accumulation, and yield between monoculture and intercropping under different $\mathrm{N}$ fertilization levels. The aims were to investigate the effect of increasing $\mathrm{N}$ applications on the advantageous effect of intercrops, and clarify the change in the trend of the effect of $\mathrm{N}$ fertilizer by enhancing the $\mathrm{N}$ fertilization level. We hypothesized that the advantageous effects of intercropping were only significant for the low $\mathrm{N}$ fertilization level (N1), and the effects of increasing $\mathrm{N}$ applications would decrease by increasing the $\mathrm{N}$ fertilization level.

\section{MATERIALS AND METHODS}

\section{Experimental design and management}

The field experiment was conducted in 2012 and 2013 at the Red Soil Experimental Station of Jiangxi Agricultural University, Nanchang City $\left(28^{\circ} 46^{\prime} \mathrm{N}, 115^{\circ} 36^{\prime} \mathrm{E}\right.$; $22 \mathrm{~m}$ a.s.1.), Jiangxi province in China. Annual mean temperature is $16-18{ }^{\circ} \mathrm{C}$ and accumulated temperatures above $10{ }^{\circ} \mathrm{C}$ were $5300-5800{ }^{\circ} \mathrm{C}$. The frost-free period is $260-280 \mathrm{~d}$ per year. The region is classified as a subtropical monsoon climate. Annual precipitation is $1450-1650 \mathrm{~mm}$. The soil used in the experiment is latosolic red soil (Orthic Acrisol, FAO-UNESCO system) derived from Quaternary red earth with a sandy-loam texture (58\% sand, $19 \%$ silt, $23 \%$ clay). Soil properties were $\mathrm{pH} 6.0,17.4 \mathrm{~g} \mathrm{~kg}^{-1}$ organic matter, $0.68 \mathrm{~g} \mathrm{~kg}^{-1}$ total $\mathrm{N}, 0.76 \mathrm{~g} \mathrm{~kg}^{-1}$ total $\mathrm{P}, 64.2 \mathrm{~g} \mathrm{~kg}^{-1}$ available $\mathrm{N}, 12.9 \mathrm{~g} \mathrm{~kg}^{-1}$ available $\mathrm{P}, 151.6 \mathrm{~g} \mathrm{~kg}^{-1}$ available $\mathrm{K}$, and $25.7 \%$ soil water capacity. These were analyzed according to the method by Bao et al. (2000).

The experiment was conducted in a randomized block design with four $\mathrm{N}$ fertilization levels $(\mathrm{N} 1, \mathrm{~N} 2, \mathrm{~N} 3$, and N4) and three cropping patterns (M, I1, and I2) as the treatment variables. This experimental plan generated 12 treatments (i.e., $4 \times 3$ ) and each treatment was replicated three times. The four N levels were N1 $\left(100 \mathrm{~kg} \mathrm{ha}^{-1}\right), \mathrm{N} 2$ $\left(200 \mathrm{~kg} \mathrm{ha}^{-1}\right), \mathrm{N} 3\left(300 \mathrm{~kg} \mathrm{ha}^{-1}\right)$, and N4 (400 kg ha-1); and the three cropping patterns were $\mathrm{M}$ (maize monoculture), I1 (maize-cotton intercrop), and I2 (maize-soybean intercrop). All plots were given a basal application of $300 \mathrm{~kg} \mathrm{P} \mathrm{ha}^{-1}$ and $200 \mathrm{~kg} \mathrm{~K} \mathrm{ha}^{-1}$. Nitrogen was supplied as urea and $\left(\mathrm{NH}_{4}\right)_{2} \mathrm{HPO}_{4}$, and $\mathrm{P}$ and $\mathrm{K}$ were applied as $\left(\mathrm{NH}_{4}\right)_{2} \mathrm{HPO}_{4}$ and $\mathrm{K}_{2} \mathrm{SO}_{4}$, respectively. All fertilizers were evenly broadcasted and incorporated into the top $20 \mathrm{~cm}$ of the soil prior to sowing.

Each plot was $33.0 \mathrm{~m}^{2}(5.5 \mathrm{~m} \times 6 \mathrm{~m})$ with $50 \mathrm{~cm}$ row spacing between neighboring plots. The selected maize, soybean (Glycine max [L.] Merr.), and cotton (Gossypium hirsutum L.) cultivars were 'Hengxing401' (local variety), 'Zao50', and 'Ganmian1', respectively. Maize, soybean, and cotton were all sown on 2 April 2012 and 2013, and maize was harvested on 18 July each year. Each intercropping plot consisted of two maize strips and three soybean or cotton strips. Each soybean and cotton strip had five planted rows, and each maize strip had two planted rows. There were 19 plants per row for maize, and each intercropping plot had 76 maize plants. Row and plant spacing for maize was 40 and $30 \mathrm{~cm}$, respectively, and row and plant spacing for soybean and cotton were both $30 \mathrm{~cm}$, while row spacing between maize and adjacent soybean (or cotton) was $40 \mathrm{~cm}$. In addition, row and plant spacing in monoculture maize was the same as in intercropping.

\section{Sampling and measurements}

Green leaf area per plant. Leaves were painted on homogeneous and transparent paper according to their shapes and then cut down with scissors because the paper texture is uniform and the weight per unit area of paper was the same. Papers which had been cut down could be converted into green leaf area by weighing. Five maize plants in each plot were selected for measurements at the maturity stage.

Chlorophyll content. It was measured with a hand-held chlorophyll meter (SPAD-502, Konica Minolta Company, Tokyo, Japan), the same leaf parts in the middle of the maize plant were selected and measured at the bellmouthed, silking, filling, and maturity stage, respectively.

Leaf photosynthetic rate, stomatal conductance, transpiration rate, and intercellular $\mathrm{CO}_{2}$ concentration were measured with a portable photosynthesis system (LI-6400, Li-Cor, Lincoln, Nebraska, USA) at 10:00 to 11:30 h local time at the filling stage. Maize ear leaves were selected for leaf measurements and each leaf was measured in three points.

Leaf and grain $\mathrm{N}$ content was analyzed by the Kjeldahl $\mathrm{N}$ determination method (Wang et al., 2006); $\mathrm{N}$ accumulation $\left(\mathrm{g} \mathrm{plant}^{-1}\right)=\mathrm{N}$ content of samples (leaves and grain) $\times$ Total biomass of samples per plant.

Root dry mass. The approximate depth of 0 to $0.5 \mathrm{~m}$ and width of $0.3 \mathrm{~m}$ of maize roots in soil were taken at the maturity stage; five maize plants were selected from each plot. Root samples (washed clean with water) were ovendried at $105^{\circ} \mathrm{C}$ for $20 \mathrm{~min}$ to stop respiration, oven-dried at $70{ }^{\circ} \mathrm{C}$ for $48 \mathrm{~h}$, and weighed immediately after being removed from the oven.

Root bleeding sap rate. Five maize stems were selected from each plot and cut at a distance of $5 \mathrm{~cm}$ from the soil surface. Dry cotton (previously weighed) was placed at the cut end, covered with a vinyl film fastened with a rubber band to collect the bleeding sap for $12 \mathrm{~h}$ (from 18:00 $\mathrm{h}$ on 20 June to $06: 00 \mathrm{~h}$ on 21 June), and then weighed to calculate the bleeding rate (Morita et al., 2000; Song and Li, 2003).

Biomass per plant. This was above-ground DM weight per maize plant. Five maize plants were selected from each plot to determine dry weight; samples were oven- 
dried at $105{ }^{\circ} \mathrm{C}$ for 30 min to stop plant respiration and then oven-dried at $70^{\circ} \mathrm{C}$ until constant dry weight.

\section{Statistical analysis}

ANOVA was performed by the general linear modelunivariate procedure from SPSS17.0 software (IBM, Armonk, New York, USA). ANOVAs were performed with the $\mathrm{N}$ level and cropping pattern as the main effects as well as their interaction. All treatment means were compared for any significant differences by the LSD multiple range tests at the significant level of $\mathrm{P}<0.05$ with the SPSS17.0 software package for Windows.

\section{RESULTS}

Green leaf area per plant and chlorophyll content at different growth stages in maize

Nitrogen fertilization and the cropping pattern had a significant effect on green leaf area per plant, but their interaction was not significant (Figure 1). When compared with the M treatment, I1 and I2 for N1, N2, N3, and N4 increased green leaf area per plant by $3.8 \%, 2.5 \%, 1.7 \%$,

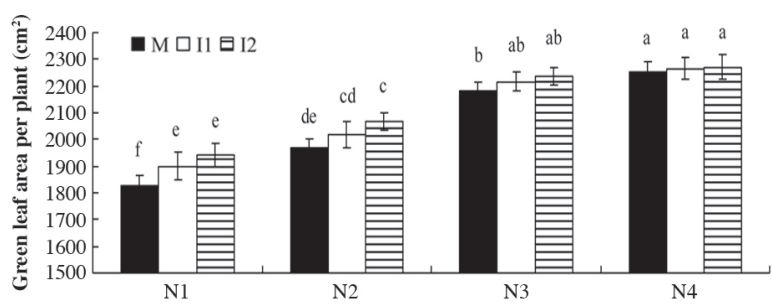

Values are means \pm standard deviation $(\mathrm{n}=3)$. Different letters above columns indicate differences for treatments of four $\mathrm{N}$ levels and three cropping patterns according to LSD tests (ANOVA) at the 5\% level. $(\mathrm{N}$ fertilization $\mathrm{P}<0.01$; Cropping pattern $\mathrm{P}<0.01$; $\mathrm{N}$ fertilization $\times$ Cropping pattern $\mathrm{P}=0.5527$ ).

M: maize monoculture; I1: maize-cotton intercrop; I2: maize-soybean intercrop; N1: $100 \mathrm{~kg} \mathrm{ha}^{-1}$; N2: $200 \mathrm{~kg} \mathrm{ha}^{-1}$; N3: $300 \mathrm{~kg} \mathrm{ha}^{-1}$; N4: 400 $\mathrm{kg} \mathrm{ha}^{-1}$.

Figure 1. Effects of intercropping and $\mathbf{N}$ fertilization on green leaf area per plant in maize at the maturity stage. and $0.5 \%$, and $6.1 \%, 5.0 \%, 2.7 \%$, and $0.7 \%$, respectively; the difference between intercropping and monoculture for $\mathrm{N} 1$ was significant $(\mathrm{P}<0.05)$. Increasing $\mathrm{N}$ applications can also enhance green leaf area per plant in maize under M, I1, and I2; when N2 was compared with N1 and N4 was compared with $\mathrm{N} 3$, green leaf area per plant increased by $7.6 \%, 6.2 \%$, and $6.5 \%$ and $3.4 \%, 2.3 \%$, and $1.4 \%$, respectively. Therefore, data from the above analysis can be used to infer that intercropping and increasing $\mathrm{N}$ applications can increase green leaf area per plant in maize, but that their effects will gradually decrease with increasing $\mathrm{N}$ fertilization levels.

Nitrogen fertilization and the cropping pattern had a significant effect on chlorophyll content but with no interaction. Within the same N level (N1, N2, N3, or N4), chlorophyll content of intercropped maize at different growth stages was higher than for monoculture (Table 1). When compared with the M treatment, I1 and I2 for N1, $\mathrm{N} 2, \mathrm{~N} 3$, and $\mathrm{N} 4$ increased chlorophyll content by $7.1 \%$, $4.9 \%, 4.5 \%$, and $9.4 \%$, and $10.7 \%, 7.5 \%, 5.6 \%$, and $10.9 \%$, respectively, at the bell-mouthed, silking, filling, and maturity stage, respectively. The difference in chlorophyll content between intercropping and monoculture for N1 was significant $(\mathrm{P}<0.05)$, while it was not significant for N3 and N4. Increasing N applications can also enhance the chlorophyll content of maize; the difference in chlorophyll content of the same cropping pattern (M, I1, or I2) between N1 and N2 was significant, while it was not significant between N3 and N4 (P>0.05). Therefore, the effect of intercropping and $\mathrm{N}$ fertilizer on increasing chlorophyll content of maize will gradually decrease with increasing $\mathrm{N}$ fertilization levels.

\section{Photosynthetic characteristics}

Nitrogen fertilization and the cropping pattern had a significant effect on maize photosynthetic characteristics, buttheirinteraction was only differentfor the photosynthetic rate (Table 2). When compared with monoculture,

Table 1. Effects of intercropping and $\mathbf{N}$ fertilization on maize chlorophyll content at different growth stages (SPAD value).

\begin{tabular}{|c|c|c|c|c|c|}
\hline $\begin{array}{l}\mathrm{N} \\
\text { fertilization }\end{array}$ & $\begin{array}{l}\text { Cropping } \\
\text { patterns }\end{array}$ & $\begin{array}{l}\text { Bell-mouthed } \\
\text { stage }\end{array}$ & Silking stage & Filling stage & Maturity stage \\
\hline \multirow[t]{3}{*}{ N1 } & $\mathrm{M}$ & $35.91 \pm 1.34 \mathrm{~h}$ & $48.89 \pm 0.77 f$ & $54.55 \pm 1.46 \mathrm{e}$ & $36.79 \pm 1.22 \mathrm{e}$ \\
\hline & I1 & $38.46 \pm 0.56 \mathrm{~g}$ & $51.31 \pm 2.02 \mathrm{e}$ & $56.99 \pm 0.93 \mathrm{~d}$ & $40.25 \pm 1.19 \mathrm{~d}$ \\
\hline & $\mathrm{I} 2$ & $39.74 \pm 0.94 \mathrm{fg}$ & $52.55 \pm 1.94 \mathrm{de}$ & $57.58 \pm 1.52 \mathrm{~cd}$ & $40.79 \pm 1.03 \mathrm{~cd}$ \\
\hline \multirow[t]{3}{*}{ N2 } & M & $40.91 \pm 0.85 \mathrm{ef}$ & $53.74 \pm 0.94 \mathrm{~d}$ & $59.50 \pm 1.04 b c$ & $41.29 \pm 1.13 \mathrm{bcd}$ \\
\hline & I1 & $42.03 \pm 1.00 \mathrm{de}$ & $54.56 \pm 1.26 \mathrm{~cd}$ & $61.38 \pm 0.84 \mathrm{ab}$ & $43.12 \pm 0.96 a b c$ \\
\hline & $\mathrm{I} 2$ & $42.74 \pm 1.45 \mathrm{cde}$ & $56.64 \pm 0.81 b c$ & $62.13 \pm 1.43 \mathrm{a}$ & $43.66 \pm 1.06 \mathrm{ab}$ \\
\hline \multirow[t]{3}{*}{ N3 } & M & $43.93 \pm 1.18 \mathrm{bcd}$ & $56.81 \pm 2.22 \mathrm{bc}$ & $61.61 \pm 1.69 \mathrm{ab}$ & $43.72 \pm 2.68 \mathrm{ab}$ \\
\hline & I1 & $44.61 \pm 1.16 \mathrm{abc}$ & $57.77 \pm 1.42 \mathrm{ab}$ & $62.52 \pm 1.94 \mathrm{a}$ & $44.68 \pm 1.48 \mathrm{a}$ \\
\hline & $\mathrm{I} 2$ & $44.80 \pm 1.48 \mathrm{abc}$ & $58.18 \pm 1.07 \mathrm{ab}$ & $62.92 \pm 1.50 \mathrm{a}$ & $44.91 \pm 2.72 \mathrm{a}$ \\
\hline \multirow[t]{3}{*}{ N4 } & M & $45.89 \pm 0.81 \mathrm{ab}$ & $58.86 \pm 0.68 \mathrm{ab}$ & $63.04 \pm 1.34 \mathrm{a}$ & $45.16 \pm 1.23 \mathrm{a}$ \\
\hline & I1 & $46.25 \pm 1.76 a$ & $59.77 \pm 1.23 \mathrm{a}$ & $63.32 \pm 1.22 \mathrm{a}$ & $45.58 \pm 1.33 \mathrm{a}$ \\
\hline & $\mathrm{I} 2$ & $46.35 \pm 1.52 \mathrm{a}$ & $60.09 \pm 1.65 \mathrm{a}$ & $63.55 \pm 2.21 \mathrm{a}$ & $45.72 \pm 2.07 \mathrm{a}$ \\
\hline \multicolumn{6}{|c|}{ Significance LSD multiple range tests (P values) } \\
\hline \multicolumn{2}{|c|}{$\mathrm{N}$ fertilization } & 0.0001 & 0.0001 & 0.0001 & 0.0001 \\
\hline \multicolumn{2}{|c|}{ Cropping pattern } & 0.0068 & 0.0024 & 0.0118 & 0.0158 \\
\hline \multicolumn{2}{|c|}{$\mathrm{N}$ fertilization $\times$ Cropping pattern } & 0.3664 & 0.6700 & 0.7476 & 0.6320 \\
\hline
\end{tabular}

Values are means \pm standard deviation $(n=3)$. Means followed by different letters in the same column indicate differences according to LSD multiple range tests $(\mathrm{P}<0.05)$.

M: maize monoculture; I1: maize-cotton intercrop; I2: maize-soybean intercrop; N1: $100 \mathrm{~kg} \mathrm{ha}^{-1} ; \mathrm{N}^{2}: 200 \mathrm{~kg} \mathrm{ha}^{-1} ; \mathrm{N}^{2}: 300 \mathrm{~kg}$ ha-1; $\mathrm{N}^{-}: 400 \mathrm{~kg}$ ha ${ }^{-1}$. 
Table 2. Effects of intercropping and $\mathrm{N}$ fertilization on maize photosynthetic characteristics at the filling stage.

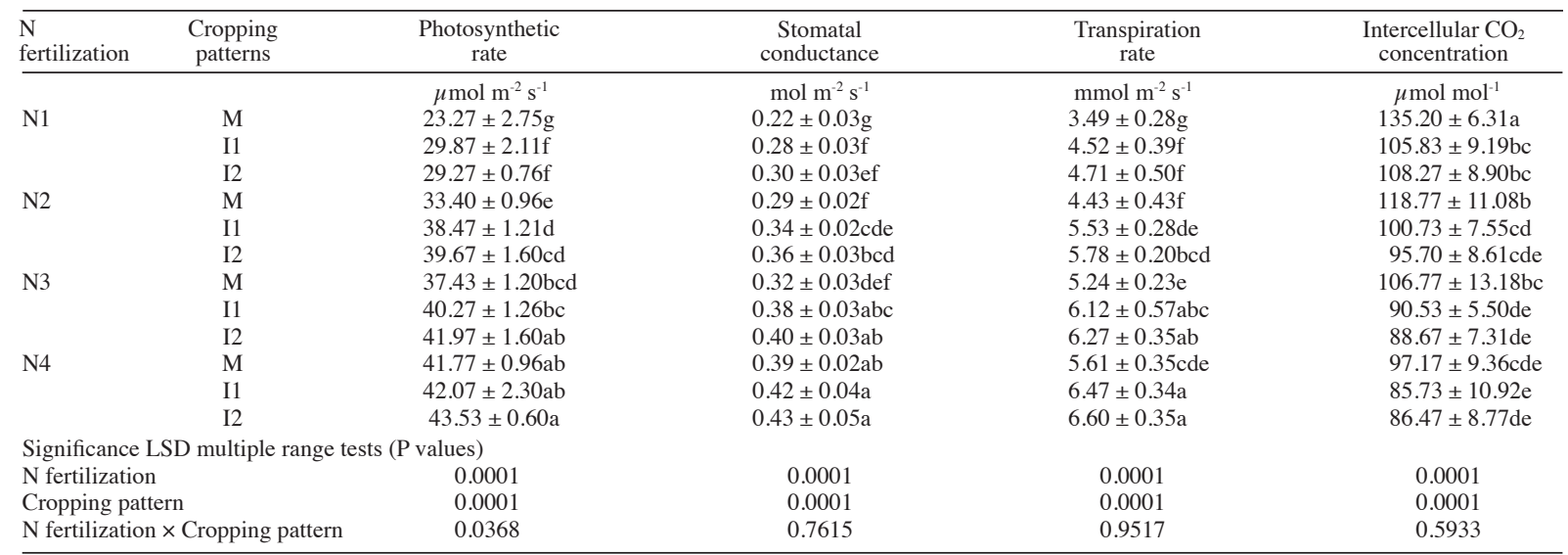

Values are means \pm standard deviation $(n=3)$. Means followed by different letters in the same column indicate differences according to LSD multiple range tests $(\mathrm{P}<0.05)$.

M: maize monoculture; I1: maize-cotton intercrop; I2: maize-soybean intercrop; N1: $100 \mathrm{~kg} \mathrm{ha}^{-1}$; N2: $200 \mathrm{~kg} \mathrm{ha}^{-1}$; N3: $300 \mathrm{~kg}$ ha-1 $\mathrm{N}^{-1} 400 \mathrm{~kg}$ ha-1.

intercropping can increase leaf photosynthetic rate, stomatal conductance, and transpiration rate, while it can decrease intercellular $\mathrm{CO}_{2}$ concentration. Moreover, the difference between intercropping and monoculture for $\mathrm{N} 1$ and $\mathrm{N} 2$ was significant $(\mathrm{P}<0.05)$, while it was not significant for $\mathrm{N} 4$ (with the exception of transpiration rate). Increasing $\mathrm{N}$ applications can also improve maize photosynthetic characteristics; the differences in photosynthetic rate, stomatal conductance, transpiration rate, and intercellular $\mathrm{CO}_{2}$ concentration of the same cropping pattern (M, I1, or I2) between $\mathrm{N} 1$ and $\mathrm{N} 2$ were mostly significant, while they were mostly not significant $(\mathrm{P}>0.05)$ between N3 and N2, and N4 and N3. Therefore, the effect of intercropping and $\mathrm{N}$ fertilizer to improve maize photosynthetic characteristics will gradually decrease with increasing $\mathrm{N}$ fertilization levels.

\section{Root bleeding sap rate and root dry mass per plant}

When compared with the M treatment, I1 and I2 for N1, $\mathrm{N} 2, \mathrm{~N} 3$, and $\mathrm{N} 4$ increased root bleeding sap rate by $7.8 \%$, $3.9 \%, 1.4 \%$, and $1.3 \%$, and $16.5 \%, 7.0 \%, 3.5 \%$, and $2.6 \%$, respectively; the difference between I2 and $\mathrm{M}$ for $\mathrm{N} 1$ and $\mathrm{N} 2$ was significant $(\mathrm{P}<0.05)$, while it was not significant for N3 and N4 (Figure 2). In addition, for M, $\mathrm{I} 1$, and $\mathrm{I} 2, \mathrm{~N} 2$ increased root bleeding sap rate by $25.2 \%$, $20.7 \%$, and $15.0 \%$ as compared with $\mathrm{N} 1$; N3 increased by $11.6 \%, 9.0 \%$, and $8.0 \%$ as compared with $\mathrm{N} 2$; and $\mathrm{N} 4$ increased by $6.3 \%, 6.2 \%$, and $5.4 \%$ as compared with $\mathrm{N} 3$. Intercropping and increasing $\mathrm{N}$ applications can increase the root bleeding sap rate of maize, but their effects will gradually decrease with increasing $\mathrm{N}$ fertilization levels.

Nitrogen fertilization and the cropping pattern had an effect on root DM per plant $(\mathrm{P}<0.005$, Figure 3$)$. When compared with the M treatment, I1 and I2 for N1, N2, $\mathrm{N} 3$, and $\mathrm{N} 4$ increased root DM by $5.4 \%, 3.8 \%, 2.0 \%$, and $1.7 \%$, and $8.6 \%, 6.7 \%, 2.8 \%$, and $1.9 \%$, respectively; the difference between $\mathrm{I} 2$ and $\mathrm{M}$ for $\mathrm{N} 1$ and N2 was significant. Increasing $\mathrm{N}$ applications can also enhance root DM of maize at the maturity stage; the difference in root DM of the same cropping pattern $(\mathrm{M}, \mathrm{I} 1$, or I2) between $\mathrm{N} 2$ and $\mathrm{N} 1$ and $\mathrm{N} 3$ and $\mathrm{N} 2$ was significant $(\mathrm{P}<$ 0.05 ), while it was not significant between $\mathrm{N} 4$ and $\mathrm{N} 3$.

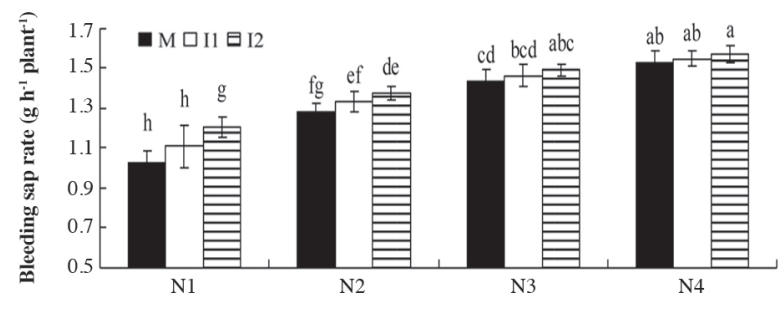

Values are means \pm standard deviation $(n=3)$. Different letters above columns indicate difference for treatments of four $\mathrm{N}$ levels and three cropping patterns according to LSD tests (ANOVA) at the 5\% level $(\mathrm{N}$ fertilization $\mathrm{P}<0.01$; Cropping pattern $\mathrm{P}<0.01$; $\mathrm{N}$ fertilization $\times$ Cropping pattern $\mathrm{P}=0.4488$ ).

M: maize monoculture; I1: maize-cotton intercrop; I2: maize-soybean intercrop; N1: $100 \mathrm{~kg} \mathrm{ha}^{-1}$; N2: $200 \mathrm{~kg} \mathrm{ha}^{-1}$; N3: $300 \mathrm{~kg} \mathrm{ha}^{-1}$; N4: 400 $\mathrm{kg} \mathrm{ha}^{-1}$.

Figure 2. Effects of intercropping and $\mathrm{N}$ fertilization on root bleeding sap rate of maize at the filling stage.

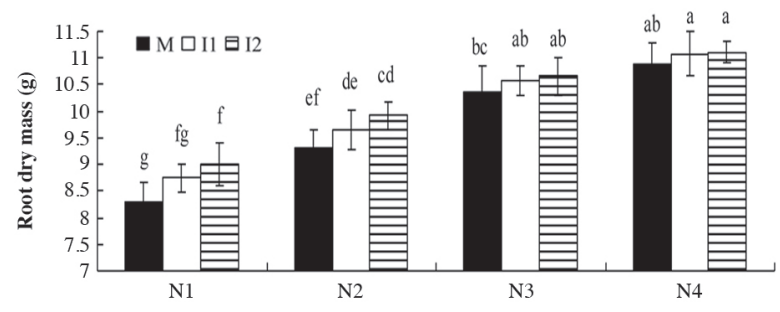

Values are means \pm standard deviation $(n=3)$. Different letters above columns indicate difference under treatments of four $\mathrm{N}$ levels and three cropping patterns according to LSD tests (ANOVA) at the $5 \%$ level ( $\mathrm{N}$ fertilization $\mathrm{P}<0.01$; Cropping pattern $\mathrm{P}<0.05$; $\mathrm{N}$ fertilization $\times$ Cropping pattern $\mathrm{P}=0.8989$ ).

M: maize monoculture; I1: maize-cotton intercrop; I2: maize-soybean intercrop; N1: $100 \mathrm{~kg} \mathrm{ha}^{-1}$; N2: $200 \mathrm{~kg} \mathrm{ha}^{-1}$; $3: 300 \mathrm{~kg} \mathrm{ha}^{-1}$; N4: 400 $\mathrm{kg} \mathrm{ha}^{-1}$.

Figure 3. Effects of intercropping and $\mathbf{N}$ fertilization on root dry mass per plant in maize at the maturity stage. 
The effect of intercropping and $\mathrm{N}$ fertilizer on increasing root DM of maize will gradually decrease with increasing $\mathrm{N}$ fertilization levels.

\section{Leaf and grain $\mathrm{N}$ content and maize yield}

Nitrogen fertilization and the cropping pattern had a significant effect on leaf and grain N content (Figure 4). When compared with the M treatment, I1 and I2 for N1, $\mathrm{N} 2, \mathrm{~N} 3$, and $\mathrm{N} 4$ increased leaf $\mathrm{N}$ content by $11.9 \%, 6.8 \%$, $4.3 \%$, and $0.1 \%$, and $21.4 \%, 11.9 \%, 4.3 \%$, and $2.6 \%$, and grain $\mathrm{N}$ content by $5.2 \%, 2.7 \%, 1.2 \%$, and $1.1 \%$, and $12.8 \%, 6.3 \%, 2.7 \%$, and $1.5 \%$, respectively. The difference in leaf and grain $\mathrm{N}$ content between intercropping and monoculture for $\mathrm{N} 3$ and $\mathrm{N} 4$ was not significant $(\mathrm{P}>0.05)$. Increasing $\mathrm{N}$ applications can also enhance leaf and grain $\mathrm{N}$ content; the difference in leaf and grain $\mathrm{N}$ content from the same cropping pattern (M, I1, or I2) between N1 and $\mathrm{N} 2$ was significant $(\mathrm{P}<0.05)$, while it was not significant between N3 and N4. The effect of intercropping and $\mathrm{N}$ fertilizer on increasing leaf and grain $\mathrm{N}$ content will gradually decrease with increasing $\mathrm{N}$ fertilization levels.

Within the same N level (N1, N2, N3, or N4), kernels per ear, 1000-kernel weight, economic yield per plant, biomass per plant, and yield of intercropped maize in 2012 and 2013 were higher than those for monoculture and the
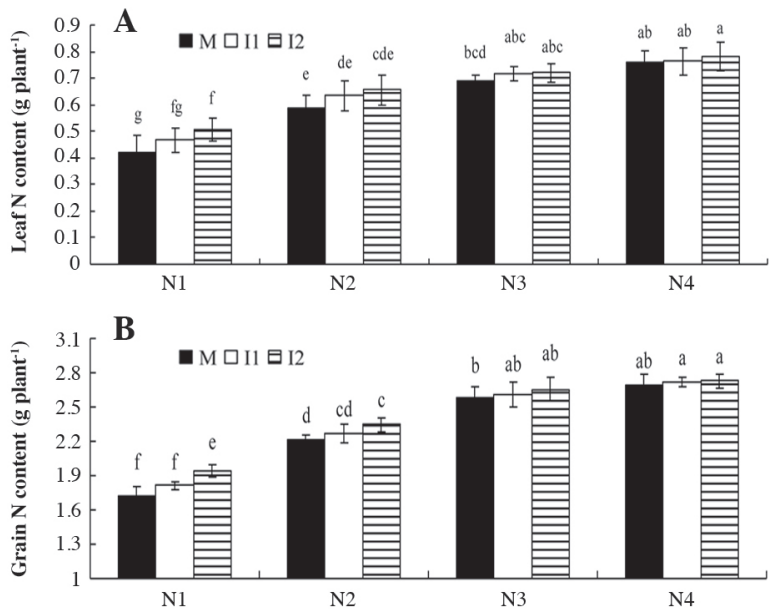

Values are means \pm standard deviation $(\mathrm{n}=3)$. Different letters above columns indicate differences for treatments of four $\mathrm{N}$ levels and three cropping patterns according to LSD test (ANOVA) at the 5\% level. (A): $\mathrm{N}$ fertilization $\mathrm{P}<0.01$; Cropping pattern $\mathrm{P}<0.05 ; \mathrm{N}$ fertilization $\times$ Cropping pattern $\mathrm{P}=0.8833$; $(\mathrm{B})$ : $\mathrm{N}$ fertilization $\mathrm{P}<0.01$; Cropping pattern $\mathrm{P}<0.01 ; \mathrm{N}$ fertilization $\times$ Cropping pattern $\mathrm{P}=0.5227$ ).

M: maize monoculture; I1: maize-cotton intercrop; I2: maize-soybean intercrop; N1: $100 \mathrm{~kg} \mathrm{ha}^{-1}$; N2: $200 \mathrm{~kg} \mathrm{ha}^{-1}$; N3: $300 \mathrm{~kg} \mathrm{ha}^{-1}$; N4: 400 $\mathrm{kg} \mathrm{ha}^{-1}$.

Figure 4. Effects of intercropping and $\mathbf{N}$ fertilization on (A) leaf and (B) grain $\mathrm{N}$ content at the maturity stage.

Table 3. Effects of intercropping and $\mathrm{N}$ fertilization on maize yield and its components.

\begin{tabular}{|c|c|c|c|c|c|c|c|}
\hline & $\begin{array}{c}\mathrm{N} \\
\text { fertilization }\end{array}$ & $\begin{array}{l}\text { Cropping } \\
\text { patterns }\end{array}$ & $\begin{array}{l}\text { Kernels } \\
\text { per ear }\end{array}$ & $\begin{array}{l}\text { 1000-kernel } \\
\text { weight }\end{array}$ & $\begin{array}{c}\text { Economic } \\
\text { yield per plant }\end{array}$ & $\begin{array}{l}\text { Biomass per } \\
\text { plant }\end{array}$ & Yield \\
\hline & & & & & & & $\mathrm{kg} \mathrm{ha}^{-1}$ \\
\hline \multirow[t]{12}{*}{2012} & N1 & M & $510.90 \pm 6.07 \mathrm{e}$ & $265.53 \pm 5.05 h$ & $118.63 \pm 6.48 \mathrm{~g}$ & $287.57 \pm 11.09 f$ & $8048.43 \pm 115.68 \mathrm{~g}$ \\
\hline & & I1 & $515.03 \pm 8.34 \mathrm{de}$ & $268.93 \pm 3.56 \mathrm{gh}$ & $122.53 \pm 5.76 \mathrm{fg}$ & $303.73 \pm 9.18 \mathrm{ef}$ & $8418.90 \pm 159.41 \mathrm{f}$ \\
\hline & & $\mathrm{I} 2$ & $524.27 \pm 4.51 d$ & $273.13 \pm 6.24 \mathrm{fg}$ & $129.27 \pm 6.24 \mathrm{ef}$ & $316.20 \pm 9.73 \mathrm{e}$ & $8511.83 \pm 143.64 \mathrm{f}$ \\
\hline & $\mathrm{N} 2$ & M & $540.83 \pm 4.12 c$ & $279.90 \pm 4.29 \mathrm{ef}$ & $135.07 \pm 6.56 \mathrm{de}$ & $335.33 \pm 12.44 d$ & $8923.53 \pm 204.52 \mathrm{e}$ \\
\hline & & I1 & $544.63 \pm 6.61 \mathrm{c}$ & $283.07 \pm 7.45 \mathrm{de}$ & $138.23 \pm 3.23 \mathrm{cde}$ & $340.23 \pm 8.53 d$ & $9137.60 \pm 166.02 \mathrm{de}$ \\
\hline & & $\mathrm{I} 2$ & $549.23 \pm 8.00 \mathrm{c}$ & $288.43 \pm 4.74 d$ & $140.10 \pm 6.26 \mathrm{~cd}$ & $347.05 \pm 13.07 \mathrm{~cd}$ & $9389.27 \pm 109.11 \mathrm{~cd}$ \\
\hline & N3 & M & $566.63 \pm 7.26 b$ & $297.20 \pm 3.82 \mathrm{c}$ & $144.37 \pm 6.42 \mathrm{bcd}$ & $359.07 \pm 7.59 \mathrm{bc}$ & $9588.03 \pm 103.87 b c$ \\
\hline & & I1 & $568.97 \pm 8.40 \mathrm{~b}$ & $301.87 \pm 6.62 b c$ & $147.23 \pm 4.57 \mathrm{abc}$ & $365.77 \pm 7.74 \mathrm{ab}$ & $9681.87 \pm 183.90 \mathrm{ab}$ \\
\hline & & $\mathrm{I} 2$ & $570.73 \pm 1.50 b$ & $301.60 \pm 6.49 b c$ & $150.87 \pm 3.99 \mathrm{ab}$ & $371.57 \pm 6.14 \mathrm{ab}$ & $9777.37 \pm 118.75 \mathrm{ab}$ \\
\hline & N4 & M & $582.87 \pm 7.56 \mathrm{a}$ & $308.27 \pm 5.58 \mathrm{ab}$ & $152.03 \pm 3.67 \mathrm{ab}$ & $373.77 \pm 10.78 \mathrm{ab}$ & $9790.57 \pm 219.08 \mathrm{ab}$ \\
\hline & & I1 & $584.33 \pm 5.04 \mathrm{a}$ & $310.07 \pm 6.11 \mathrm{a}$ & $154.93 \pm 6.07 \mathrm{a}$ & $375.40 \pm 9.45 \mathrm{a}$ & $9874.37 \pm 111.70 \mathrm{a}$ \\
\hline & & $\mathrm{I} 2$ & $586.23 \pm 6.26 \mathrm{a}$ & $311.93 \pm 6.23 a$ & $156.03 \pm 6.92 a$ & $376.83 \pm 8.95 a$ & $9924.43 \pm 138.72 \mathrm{a}$ \\
\hline \multicolumn{8}{|c|}{ Significance LSD multiple range tests (P values) } \\
\hline $\mathrm{N}$ fert & zation & & 0.0001 & 0.0001 & 0.0001 & 0.0001 & 0.0001 \\
\hline Cropp & g pattern & & 0.0426 & 0.0052 & 0.0407 & 0.0066 & 0.0003 \\
\hline $\mathrm{N}$ fert & zation $\times$ Cropp & pattern & 0.8748 & 0.8657 & 0.9673 & 0.4875 & 0.3800 \\
\hline \multirow[t]{12}{*}{2013} & N1 & M & $508.10 \pm 13.51 \mathrm{~h}$ & $262.77 \pm 5.92 \mathrm{~g}$ & $113.43 \pm 5.16 \mathrm{~g}$ & $288.17 \pm 17.92 \mathrm{f}$ & $8002.47 \pm 101.41 \mathrm{i}$ \\
\hline & & I1 & $513.53 \pm 6.66 \mathrm{gh}$ & $267.17 \pm 6.86 \mathrm{fg}$ & $118.13 \pm 8.41 \mathrm{~g}$ & $303.73 \pm 9.27 \mathrm{ef}$ & $8332.93 \pm 102.96 h$ \\
\hline & & $\mathrm{I} 2$ & $523.93 \pm 8.02 \mathrm{fg}$ & $275.67 \pm 6.95 \mathrm{ef}$ & $127.20 \pm 8.58 \mathrm{f}$ & $322.90 \pm 10.97 \mathrm{de}$ & $8577.00 \pm 96.15 \mathrm{~g}$ \\
\hline & $\mathrm{N} 2$ & M & $535.27 \pm 6.66 \mathrm{ef}$ & $280.50 \pm 5.82 \mathrm{de}$ & $132.90 \pm 6.66 \mathrm{ef}$ & $333.47 \pm 13.31 \mathrm{~cd}$ & $8850.20 \pm 145.69 \mathrm{f}$ \\
\hline & & I1 & $539.73 \pm 9.06 \mathrm{e}$ & $284.00 \pm 6.35 \mathrm{cde}$ & $138.20 \pm 6.78 \mathrm{de}$ & $342.97 \pm 10.43 b c$ & $9095.43 \pm 94.88 \mathrm{e}$ \\
\hline & & $\mathrm{I} 2$ & $546.97 \pm 9.58 \mathrm{de}$ & $288.13 \pm 6.33 \mathrm{~cd}$ & $142.20 \pm 6.45 \mathrm{~cd}$ & $344.10 \pm 11.32 b c$ & $9286.13 \pm 116.18 \mathrm{~d}$ \\
\hline & N3 & M & $560.77 \pm 7.12 \mathrm{~cd}$ & $292.40 \pm 6.37 b c$ & $144.53 \pm 8.30 \mathrm{bcd}$ & $356.40 \pm 9.79 a b$ & $9567.97 \pm 103.76 c$ \\
\hline & & I1 & $565.57 \pm 12.87 b c$ & $299.17 \pm 7.89 a b$ & $147.20 \pm 11.15 \mathrm{abc}$ & $364.10 \pm 9.73 a$ & $9672.03 \pm 90.29 b c$ \\
\hline & & $\mathrm{I} 2$ & $567.13 \pm 6.67 \mathrm{abc}$ & $301.70 \pm 3.21 \mathrm{ab}$ & $150.53 \pm 9.27 \mathrm{abc}$ & $367.17 \pm 7.72 \mathrm{a}$ & $9711.67 \pm 109.77 \mathrm{abc}$ \\
\hline & N4 & M & $578.70 \pm 9.76 \mathrm{ab}$ & $306.77 \pm 4.08 \mathrm{a}$ & $151.07 \pm 9.25 \mathrm{ab}$ & $368.23 \pm 10.81 \mathrm{a}$ & $9740.07 \pm 120.94 \mathrm{abc}$ \\
\hline & & I1 & $580.67 \pm 11.19 \mathrm{ab}$ & $307.80 \pm 2.65 a$ & $152.87 \pm 10.96 \mathrm{ab}$ & $369.77 \pm 13.56 \mathrm{a}$ & $9858.40 \pm 112.42 \mathrm{ab}$ \\
\hline & & $\mathrm{I} 2$ & $582.03 \pm 7.20 \mathrm{a}$ & $308.20 \pm 6.32 \mathrm{a}$ & $154.77 \pm 11.21 \mathrm{a}$ & $370.37 \pm 8.15 a$ & $9873.00 \pm 105.11 \mathrm{a}$ \\
\hline \multicolumn{8}{|c|}{ Significance LSD multiple range tests (P values) } \\
\hline $\mathrm{N}$ fert & zation & & 0.0001 & 0.0001 & 0.0001 & 0.0001 & 0.0001 \\
\hline Cropp & g pattern & & 0.0681 & 0.0147 & 0.0028 & 0.0202 & 0.0001 \\
\hline $\mathrm{N}$ fert & zation $\times$ Cropp & gattern & 0.9258 & 0.7530 & 0.7224 & 0.3813 & 0.0620 \\
\hline
\end{tabular}

Values are means \pm standard deviation $(\mathrm{n}=3)$. Means followed by different letters in the same column indicate differences according to LSD multiple range tests $(\mathrm{P}<0.05)$.

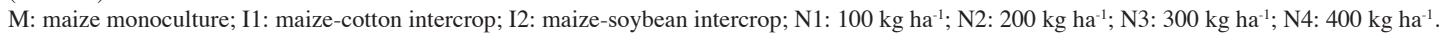


difference between $\mathrm{I} 2$ and $\mathrm{M}$ for $\mathrm{N} 1$ was significant $(\mathrm{P}<$ 0.05 , Table 3). When compared with the $\mathrm{M}$ treatment, I2 for $\mathrm{N} 1, \mathrm{~N} 2, \mathrm{~N} 3$, and $\mathrm{N} 4$ increased yield in 2012 by $5.8 \%$, $5.2 \%, 2.0 \%$, and $1.4 \%$, and in 2013 by $7.2 \%, 4.9 \%, 1.5 \%$, and $1.4 \%$, respectively. The results of the $2 \mathrm{yr}$ also showed that increasing $\mathrm{N}$ applications can enhance kernels per ear, 1000-kernel weight, economic yield per plant, biomass per plant, and yield of maize; the difference in yield of the same cropping patterns (S, I1 or I2) between N2 and N1 and N3 and N2 was significant, while it was not significant (P $>0.05$ ) between N4 and N3. The effect of intercropping and $\mathrm{N}$ fertilizer on increasing maize yield will gradually decrease when the $\mathrm{N}$ fertilization level increases.

\section{DISCUSSION}

The advantageous effect of intercropping has been confirmed by many experiments (Zuo et al., 2000; Peng et al., 2009; Hinsinger et al., 2011). In this study, when compared with the $\mathrm{M}$ treatment, I1 and I2 for N1, N2, $\mathrm{N} 3$, and $\mathrm{N} 4$ increased green leaf area per plant by $3.8 \%$, $2.5 \%, 1.7 \%$, and $0.5 \%$, and $6.1 \%, 5.0 \%, 2.7 \%$, and $0.7 \%$, respectively; this indicates that intercropping also has an advantageous effect on increasing green leaf area per plant in maize at the maturity stage, but its effect will gradually decrease when the $\mathrm{N}$ fertilization level increases. Intercropping can increase green leaf area per plant in maize mainly because one plant species enhances the survival, growth, or fitness of another in the intercropping system (Hauggaard-Nielsen and Jensen, 2005; Zhang et al., 2013). Zuo et al. (2000) indicated that rhizosphere interactions in a peanut-maize intercropping system could improve Fe nutrition of peanut and enhance its chlorophyll content. In this study, we not only found that intercropping and increasing $\mathrm{N}$ applications could increase chlorophyll content of maize at different growth stages, but we also found that their effects would gradually decrease with increasing $\mathrm{N}$ fertilization levels. Chu et al. (2004) also observed that chlorophyll content of rice leaves under intercropping conditions on 8 August and 15 September were 44.3 and 42.8 (SPAD) compared with 38.5 and 30.9 under monocropping conditions, respectively. Improving photosynthetic characteristics has a significant impact on crop yield, growth, and development (Anten, 2005). In the present study, we found that intercropping and increasing $\mathrm{N}$ applications could improve the photosynthetic characteristics of maize, but their effects would gradually decrease when the $\mathrm{N}$ fertilization level increases. In this experiment, the increase of maize leaf photosynthetic rate was mainly due to the difference in plant height between intercrops, which significantly improved the ventilation and light conditions of the maize population.

Structural and functional characteristics of roots have a significant influence on crop yield and the capacity of roots to acquire nutrients (Richardson et al., 2009; Miyazawa et al., 2010). In the present study, intercropping and increasing
$\mathrm{N}$ applications can increase root bleeding sap rate (an index of root activity) and root DM, but their effects will gradually decrease when the $\mathrm{N}$ fertilization level increases. Miyazawa et al. (2010) also found that sorghum under intercropping grew deeper roots with greater biomass than under sole cropping. Intercropping can increase root bleeding sap and root DM of maize mainly because above-ground and below-ground (root) interactions in the intercropping system can improve rhizosphere soil enzyme activities and microbial environment (Sun et al., 2011; Hinsinger et al., 2011), physical and chemical properties (Wang et al., 2005; Richardson et al., 2009), and the crop's growth and development status (Hauggaard-Nielsen and Jensen, 2005; Zhang et al., 2010). Nitrogen plays an important role in crop growth and the development process; in the present study, we found that intercropping and increasing $\mathrm{N}$ applications could enhance leaf and grain $\mathrm{N}$ content of maize at the maturity stage, but their effects would decrease when the $\mathrm{N}$ fertilization level increased. Li et al. (2001) also indicated that $\mathrm{N}$ uptake by intercropping of wheat and maize was greater than the corresponding sole cropping under the same $\mathrm{N}$ supply level. Intercropping can increase leaf and grain $\mathrm{N}$ content of maize mainly because (1) interspecific interactions in the rhizosphere facilitate $\mathrm{N}$ uptake in intercropping systems (Li et al., 2003; Richardson et al., 2009), and (2) legumes can transfer fixed $\mathrm{N}$ to intercropped cereals during their joint growing period, this $\mathrm{N}$ is an important resource for the cereals (Li et al., 2009; Rivest et al., 2010). Li et al. (1999) found that total biomass and grain yields in a field study of intercropped maize and faba bean (Vicia faba L.) were significantly higher than those of maize and faba bean in the corresponding sole crops. In our 2-yr field experiment, we found that yields of intercropped maize in 2012 and 2013 were higher than for monoculture, and the difference between I2 and M for N1 and N2 was significant. We also found that the effects of intercropping and increasing $\mathrm{N}$ applications would decrease when the $\mathrm{N}$ fertilization level increased. As abovementioned, intercropping can significantly enhance crop yield in N1 mainly because intercropping can obviously help to improve green leaf area per plant, chlorophyll content, photosynthetic rate, root biomass, and yield components of a crop with a low $\mathrm{N}$ fertilization level. Intercropping did not significantly affect yield in N3 and N4 mainly because the increasing $\mathrm{N}$ applications improved crop growth and development, which aggravated interspecific competition between intercrops; the advantageous effects of intercropping to improve crop physiological traits, yield components, and soil biochemical characteristics can be partially inhibited under high $\mathrm{N}$ fertilization levels.

\section{CONCLUSIONS}

Given that the advantageous effect of intercropping and increasing $\mathrm{N}$ applications to improve crop physiological characters and increasing crop yield will gradually 
decrease or be partially inhibited by increasing the $\mathrm{N}$ fertilization level, we should pay attention to adopting reasonable cropping patterns in agricultural production practices, increase crop yield by enhancing crop fertilizer use efficiency, and making better use of niche complementarity and interspecific facilitation of intercrops rather than by a high fertilizer input rate.

\section{ACKNOWLEDGEMENTS}

We are grateful for the research grants received from the Outstanding Youth Fund of Anhui Academy of Agricultural Sciences (14B0202) and Chinese National Natural Science Fund (U1033004) .

\section{LITERATURE CITED}

Anten, N.P.R. 2005. Optimal photosynthetic characteristics of individual plants in vegetation stands and implications for species coexistence. Annals of Botany 95:495-506.

Bao, S.D., R.F. Wang, C.G. Yang, G.H. Xu, and X.R. Han. 2000. Soil and agricultural chemistry analysis. p. 25-113. Agriculture Publication, Beijing, China.

Callaway, R.M. 1995. Positive interactions among plants. Botanical Review 61:306-349.

Chu, G.X., Q.R. Shen, and J.L. Cao. 2004. Nitrogen fixation and $\mathrm{N}$ transfer from peanut to rice cultivated in aerobic soil in an intercropping system and its effect on soil $\mathrm{N}$ fertility. Plant and Soil 263:17-27.

Fridley, J.D. 2001. The influence of species diversity on ecosystem productivity: How, where, and why? Oikos 93:514-526.

Hauggaard-Nielsen, H., and E.S. Jensen. 2001. Evaluating pea and barley cultivars for complementarity in intercropping at different levels of soil N availability. Field Crops Research 72:185-196.

Hauggaard-Nielsen, H., and E.S. Jensen. 2005. Facilitative root interactions in intercrops. Plant and Soil 274:237-250.

Hinsinger, P., E. Betencourt, L. Bernard, A. Brauman, C. Plassard, J. Shen, et al. 2011. P for two, sharing a scarce resource: Soil phosphorus acquisition in the rhizosphere of intercropped species. Plant Physiology 156:1078-1086.

Kavamahanga, F., U.R. Bishnoi, and K. Aman. 1995. Influence of different $\mathrm{N}$ rates and intercropping methods on grain sorghum, common bean, and soya bean yields. Tropical Agriculture 72:257260.

Keddy, P.A. 1989. Competition. Chapman and Hall, New York, USA.

Li, Y., W. Ran, R. Zhang, S. Sun, and G. Xu. 2009. Facilitated legume nodulation, phosphate uptake and nitrogen transfer by arbuscular inoculation in an upland rice and mung bean intercropping system. Plant and Soil 315:285-296.

Li, Q.Z., J.H. Sun, X.J. Wei, P. Christie, F.S. Zhang, and L. Li. 2011. Overyielding and interspecific interactions mediated by nitrogen fertilization in strip intercropping of maize with faba bean, wheat and barley. Plant and Soil 339:147-161.

Li, L., J. Sun, F. Zhang, X. Li, S. Yang, and Z. Rengel. 2001. Wheat/ maize or wheat/soybean strip intercropping: I. Yield advantage and interspecific interactions on nutrients. Field Crops Research $71: 123-137$.
Li, L., S. Yang, X. Li, F. Zhang, and P. Christie. 1999. Interspecific complementary and competitive interactions between intercropped maize and faba bean. Plant and Soil 212:105-114.

Li, L., F. Zhang, X. Li, P. Christie, J. Sun, S. Yang, and C. Tang. 2003. Interspecific facilitation of nutrient uptake by intercropped maize and faba bean. Nutrient Cycling in Agroecosystems 65:6171

Morita, S., M. Okamoto, J.Abe, and J. Yamagishi. 2000. Bleeding rate of field-grown maize with reference to root system development Japanese Journal of Crop Science 69:80-85

Miyazawa, K., T. Murakami, M. Takeda, and T. Murayama. 2010. Intercropping green manure crops-effects on rooting patterns. Plant and Soil 331:231-239.

Peng, X., Y. Zhang, J. Cai, Z. Jiang, and S. Zhang. 2009 Photosynthesis, growth and yield of soybean and maize in a treebased agroforestry intercropping system on the Loess Plateau. Agroforestry Systems 76:569-577.

Richardson, A.E., J.M. Barea, A.M. McNeill, and C. PrigentCombaret. 2009. Acquisition of phosphorus and nitrogen in the rhizosphere and plant growth promotion by microorganisms. Plant and Soil 321:305-339.

Rivest, D., A. Cogliastro, R.L. Bradley, and A. Olivier. 2010 Intercropping hybrid poplar with soybean increases soil microbial biomass, mineral N supply and tree growth. Agroforestry Systems 80:33-40

Schippers, P., I. Snoeijing, and M.J. Kropff. 1999. Competition under high and low nutrient levels among three grassland species occupying different positions in a successional sequence. New Phytologist 143:547-559.

Song, H., and S. Li. 2003. Effects of water and N supply on maize bleeding sap and its nutrient contents. Plant Nutrition and Fertilizer Science 10:574-578.

Sun, M., D. Fu, Y. Teng, Y. Shen, Y. Luo, Z. Li, et al. 2011. In situ phytoremediation of $\mathrm{PAH}$-contaminated soil by intercropping alfalfa (Medicago sativa L.) with tall fescue (Festuca arundinacea Schreb.) and associated soil microbial activity. Journal of Soils and Sediments 11:980-989.

Wang, H., Y. Huang, H. Huang, K.M. Wang, and S.Y. Zhou. 2005 Soil properties under young Chinese fir-based agroforestry system in mid-subtropical China. Agroforestry Systems 64:131-141.

Wang, X.K., W.H. Zhang, Z.B. Hao, X.R. Li, Y.Q. Zhang, and S.M. Wang. 2006. Principles and techniques of plant physiological biochemical experiment. p. 118-119. Higher Education Press, Beijing, China (In Chinese).

Zhang, X., G. Huang, X. Bian, and Q. Zhao. 2013. Effects of root interaction and nitrogen fertilization on the chlorophyll content, root activity, photosynthetic characteristics of intercropped soybean and microbial quantity in the rhizosphere. Plant Soil and Environment 59:80-88.

Zhang, N.N., Y.M. Sun, L. Li, E.T. Wang, W.X. Chen, and H.L. Yuan. 2010. Effects of intercropping and Rhizobium inoculation on yield and rhizosphere bacterial community of faba (Vicia faba L.) Biology and Fertility of Soils 46:625-639.

Zuo, Y., F. Zhang, X. Li, and Y. Cao. 2000. Studies on the improvement in iron nutrition of peanut by intercropping with maize on a calcareous soil. Plant and Soil 220:13-25. 